\title{
Phytotherapy for the prevention of exacerbation of chronic pyelonephritis in pregnant women
}

\begin{abstract}
The search for means to enhance the effectiveness of prevention of chronic pyelonephritis during pregnancy in obstetrical practice is urgent. The purpose of the study was to evaluate the efficacy of the herbal preparation Canephron ${ }^{\circledR} \mathrm{N}$ for preventing the recurrence of pyelonephritis during pregnancy at critical gestational age. A total number of 100 pregnant women divided into four groups participated in the study. Three groups took phytopreparation of Canephron ${ }^{\circledR} \mathrm{N}$ at various stages of pregnancy critical for exacerbation of the disease. It was observed that the usage of Canephron ${ }^{\circledR} N$ therapy during pregnancy significantly reduced $(p<0.05)$ the recurrence of chronic pyelonephritis in all experimental groups compared to the control group. This monotherapy with Canephron ${ }^{\circledR} \mathrm{N}$ improves anatomic and functional state of the urinary tract by reducing the size of pyelocaliceal system and minimizing bacteriuria Prophylactic therapy with Canephron ${ }^{\circledR} \mathrm{N}$ initiated in the critical stages of gestation of 10-12, 22-24 and 34-36 weeks prevents the exacerbation of chronic pyelonephritis.
\end{abstract}

Keywords: urogenital infections, chronic, pyelonephritis, pregnancy, phytotherapy
Volume 7 Issue 5 - 2018

\section{Khuraseva $A B$, Brimpong BB, Acquah $A$, Odiase BE}

Department of Obstetrics and Gynecology, Kursk State Medical University, Kursk, Russia

Correspondence: Khuraseva AB, Department of Obstetrics and Gynecology, Faculty of Postgraduate Education, Kursk State Medical University, Ministry of Health of Russian Federation, 305040, Karl Max Street 3, Kursk, Russia,

Emailanna_mail@bk.ru

Received: September 04, 2018 | Published: November 16 2018

\section{Introduction}

In recent years, the concept of $\mathrm{P} 4$ medicine, proposed by Professor Leroy Hood, is becoming increasingly relevant, which implies predictive, preventive, personalized and participatory approach to the diagnosis and therapy of various diseases. ${ }^{1}$

In our opinion, the $\mathrm{P} 4$ principle of medicine is especially promising for the treatment-diagnostic approach in the management of pregnant women with urinary tract infections (UTIs). This is due, on the one hand, to the significant frequency of this pathology, which varies from 10 to $48 \%$ according to different data, and on the other hand is explained by the fact that UTIs in pregnant women are a risk factor for various complications that contribute to maternal and perinatal morbidity and mortality. ${ }^{2,3}$ Complicating the course of pregnancy and childbirth UTIs, are the cause of intrauterine infection (UIE), lead to miscarriage and perinatal morbidity and mortality. ${ }^{4-7}$ The prerequisites for the emergence and progression of pyelonephritis during pregnancy are the anatomical and functional features peculiar to the gestational process. ${ }^{8}$ Based on the anatomical features of the urinary tract during pregnancy, three critical periods can be identified depending on the trimester: 1st-6-12 weeks, when the uterus is located in the small pelvis, directly behind the bladder and exerts pressure on it; 2nd - 20-24 weeks, when the uterus is in the abdominal cavity and promotes compression of both ureters and kidneys; 3rd - 36-38 weeks, when the presenting part of the fetus puts pressure on the bladder.

Prevention of recurrences of chronic pyelonephritis during pregnancy will reduce the frequency of obstetric complications. However, the use of antimicrobials during pregnancy requires compliance with a number of conditions. First, it is possible to use only medicines whose safeties are unquestionable, and secondly, the duration of pregnancy should be taken into account. ${ }^{9,10}$ In clinical observations, the fetotoxic effect of the drug Canephron ${ }^{\circledR} \mathrm{N}$ has not been established, and the incidence of birth defects in newborns is even lower than population values. ${ }^{11}$ In this regard, the use of this phytotherapy in obstetric practice is logical and justified.
The purpose of the study was to evaluate the efficacy of the herbal preparation Canephron ${ }^{\circledR} \mathrm{N}$ for preventing the recurrence of pyelonephritis during pregnancy at critical gestational age.

\section{Materials and methods of research}

The study involved 100 women of reproductive age from 20 to 36 years old who took phytopreparation of Canephron ${ }^{\circledR} \mathrm{N}$ at various stages of pregnancy. Inclusion criteria: history of chronic pyelonephritis, absence of clinical and laboratory signs of exacerbation of chronic pyelonephritis, single pregnancy, observation with 1-st trimester of pregnancy and the patient's consent to research and treatment. Exclusion criteria: absence of chronic pyelonephritis in the anamnesis, multiple pregnancies. Canephron ${ }^{\circledR} \mathrm{N}$ was administered 50 drops 3 times a day or 2 tablets 3 times a day; the course duration was 3 weeks. Depending on the timing and frequency of preventive therapy courses, the patients were divided into 4 groups. The first group included women $(\mathrm{n}=26)$ who received 3 preventive courses for 10-12, 22-24 and 34-36 weeks of pregnancy; the intervals between the courses were 10 weeks. It should be noted that these terms of preventive therapy were chosen not accidentally, but taking into account anatomical and physiological features, when the compression of the urinary tract, the pregnant uterus is most pronounced.

The second group consisted of patients $(n=24)$, who received only 2 courses of preventive therapy at 10-12 and 22-24 weeks of gestation. Patients of the 3 rd group $(n=22)$ received therapy only in the 1 st trimester of pregnancy. Women of the 4 th group (control group) did not receive preventive therapy during pregnancy. A complex examination was carried out, including clinical, laboratory and echographic methods. Statistical processing of the results of the study included: calculation of absolute, relative and average values, their errors; the correlation coefficient and their errors, the estimation of the reliability of differences by the Student criterion on a personal computer using the programs "Statgraphics" and Microsoft Excel. Forstatistically significant differences were accepted at $p<0.05$. 


\section{Results of the study and discussion}

When comparing the clinical and anamnestic data of the patients of the study groups, it was found that each 2 nd woman in the 4th group, who had not undergone preventive herbal medicine, had exacerbation of chronic pyelonephritis, which was significantly more frequent than in other groups (Table 1). Even in patients who received Canephron ${ }^{\circledR}$ $\mathrm{N}$ only for 10-12 weeks, relapse of pyelonephritis during pregnancy was 2 times less, respectively, $27.3 \pm 9.5 \%$ versus $57.1 \pm 9.4 \%\left(\mathrm{p}_{3-4}\right.$ $<0.05)$. Ultrasonic signs of pyelectasia $(10-15 \mathrm{~mm}$ at a norm of up to $10 \mathrm{~mm})$ and hydrocalycosis $(7-12 \mathrm{~mm}$ at a norm of up to $5 \mathrm{~mm}$ ) were diagnosed in the 4th group in $64.3 \pm 9.1 \%$, which was 3.5 times more often in comparison with the group, where at critical periods, Kanefron ${ }^{\circledR} \mathrm{H}$ was administered (Table 1). Concrements and anomalies in the structure of the urinary system in the examined women were not detected. Data on the incidence of asymptomatic bacteriuria in patients before the initiation of therapy in the first trimester of pregnancy and immediately before the onset of labor were analyzed (Table 2). Thus, before the prophylactic therapy, the proportion of patients with asymptomatic bacteriuria in all groups did not differ statistically: $26.9 \pm 8.7 \%, 33.3 \pm 9.6 \%, 27.3 \pm 9.5 \%, 21.4 \pm 7.8 \%$. Against the backdrop of the use of the drug Kanefron ${ }^{\circledR} N$, the frequency of asymptomatic bacteriuria decreased by 1.7 times in patients receiving 3 prophylactic courses. In contrast, in the 4th group, where preventive therapy was not used, the proportion of asymptomatic bacteriuria increased 2-fold. Before giving birth, the incidence of asymptomatic bacteriuria was significantly lower in the 1st group than in the 3rd and 4th group; $15.47 .1 \%$ versus $40.9 \pm 10.5 \%$ and $42.9 \pm 9.4 \%(p<0.05)$ respectively. It is important to note that there were no negative side effects when using the drug Kanefron ${ }^{\circledR}$ N.

Table I Results of the effectiveness of therapy in the compared groups

\begin{tabular}{|c|c|c|c|c|c|c|c|c|c|}
\hline \multirow[t]{3}{*}{ Options } & $1^{\text {st }}$ group & & $2^{\text {nd }}$ group & & $3^{\text {rd }}$ group & & $4^{\text {th }}$ group & & $\mathbf{p}$ \\
\hline & $n=26$ & & $n=24$ & & $\mathrm{n}=22$ & & $n=28$ & & \\
\hline & Abs. & $\mathbf{M} \pm \mathbf{m} \%$ & Abs. & $\mathbf{M} \pm \mathbf{m} \%$ & Abs. & $\mathbf{M} \pm \mathbf{m} \%$ & Abs. & $\mathbf{M} \pm \mathbf{m} \%$ & \\
\hline \multirow{3}{*}{$\begin{array}{l}\text { Exacerbation } \\
\text { of chronic } \\
\text { pyelonephritis } \\
\text { during pregnancy }\end{array}$} & 2 & $7,7 \pm 5,2$ & 4 & $16,7 \pm 7,6$ & 6 & $27,3 \pm 9,5$ & 16 & $57,1 \pm 9,4$ & $\mathrm{p}_{1-4}<0,01$ \\
\hline & & & & & & & & & $\mathrm{p}_{2-4}<0,01$ \\
\hline & & & & & & & & & $\mathrm{p}_{3-4}<0,05$ \\
\hline \multirow[t]{2}{*}{$\begin{array}{l}\text { US signs of } \\
\text { pyelectasia and } \\
\text { hydrocalycosis }\end{array}$} & 3 & $11,5 \pm 6,3$ & 6 & $25,0 \pm 8,8$ & 9 & $40,9 \pm 10,5$ & 18 & $64,3 \pm 9,1$ & $\mathrm{p}_{1-3}<0,05$ \\
\hline & & & & & & & & & $\mathrm{p}_{1-4}<0,001$ \\
\hline
\end{tabular}

Table 2 The incidence of asymptomatic bacteriuria before and after treatment in the compared groups (M $\pm m$ \%)

\begin{tabular}{|c|c|c|c|c|c|c|c|c|c|}
\hline \multirow[t]{3}{*}{ Options } & \multicolumn{2}{|c|}{$1^{\text {st }}$ group $n=26$} & \multicolumn{2}{|c|}{$2^{\text {nd }}$ group $n=24$} & \multicolumn{2}{|l|}{$3^{\text {rd }}$ group $n=22$} & \multicolumn{2}{|l|}{$\begin{array}{l}4^{\text {th }} \text { group } \\
n=28\end{array}$} & \multirow[t]{3}{*}{$\mathbf{p}$} \\
\hline & $\begin{array}{l}\text { Before } \\
\text { treatment }\end{array}$ & $\begin{array}{l}\text { Before } \\
\text { childbirth }\end{array}$ & $\begin{array}{l}\text { Before } \\
\text { treatment }\end{array}$ & $\begin{array}{l}\text { Before } \\
\text { childbirth }\end{array}$ & Before treatment & $\begin{array}{l}\text { Before } \\
\text { childbirth }\end{array}$ & $\begin{array}{l}\text { Before } \\
\text { treatment }\end{array}$ & $\begin{array}{l}\text { Before } \\
\text { childbirth }\end{array}$ & \\
\hline & I trimester & III trimester & I trimester & III trimester & I trimester & $\begin{array}{l}\text { III } \\
\text { trimester }\end{array}$ & I trimester & $\begin{array}{l}\text { III } \\
\text { trimester }\end{array}$ & \\
\hline \multirow[t]{2}{*}{$\begin{array}{l}\text { Asymptomatic } \\
\text { bacteriuria }\end{array}$} & $\mathrm{n}=7$ & $\mathrm{n}=4$ & $\mathrm{n}=8$ & $\mathrm{n}=6$ & $\mathrm{n}=6$ & $\mathrm{n}=9$ & $\mathrm{n}=6$ & $\mathrm{n}=12$ & ${ }_{1-4}^{\mathrm{p}}<0,05$ \\
\hline & $26,9 \pm 8,7$ & $15,4 \pm 7,1$ & $33,3 \pm 9,6$ & $25,0 \pm 8,8$ & $27,3 \pm 9,5$ & $40,9 \pm 10,5$ & $21,4 \pm 7,8$ & $42,9 \pm 9,4$ & $\underset{1-3}{\mathrm{p}}<0,05$ \\
\hline
\end{tabular}

\section{Conclusion}

Thus, the use of phytopreparation Kanefron ${ }^{\circledR} H$ during pregnancy significantly reduces the frequency of recurrences of chronic pyelonephritis, improves the anatomical and functional state of the urinary tract by reducing the size of the pyelocaliceal system and minimizing bacteriuria. The most effective period this preventive treatment is at the gestational age; 10-12, 22-24 and 34-36 weeks, where the functioning of the urinary system is most vulnerable during pregnancy.

\section{Acknowledgments}

None.

\section{Conflict of interest}

The author declares there is no conflict of interest.

\section{References}

1. Flores Mauricio, Glusman Gustavo, Brogaard Kristin, et al. P4 medicine: how systems medicine will transform the healthcare sector and society. Personalized Medicine. 2013;10(6):565-576.

2. Hill JB, Sheffield JS, McIntire DD, et al. Acute pyelonephritis in pregnancy. Obstet Gynecol. 2005;105(1):18-23.

3. Wing DA, Fassett MJ, Getahun D. Acute pyelonephritis in pregnancy: an 18-year retrospective analysis. Am J Obstet Gynecol. 2014;210(3):219e. 
4. Kadimova Sh G. Estimation of the functional condition of a fetus of pregnancy in chronic pyelonephritis. Vestn Ross Akad Med Nauk. $2013 ; 12(1) ; 80-82$

5. Sharma P, Thapa L. Acute pyelonephritis in pregnancy: a retrospective study. Aust NZS Obstet Gynec. 2007;47(4):313-315.

6. Klimkin A, Freydin A, Petrov S, et al. Chronic pyelonepritis of pregnancy. Doctor. 2017;2(1):22-24.

7. Klycheva OI, Lazareva GA, Khuraseva AB. Interrelation of somatic and gynecological diseases of the mother with the development of fetal development retardation syndrome. Proceedings of the XV-th All-Russian Scientific Forum "Mother and Child”. 2014. 683 p.

8. Farkash E, Weintraub AY, Sergienko R, et al. Acute antepartum pyelonephritis in pregnancy: a critical analysis of risk factors and outcomes. Eur J Obstet Gynecol Reprod Biol. 2012;162(1):24-27.
9. Pazos Otero N, Enentes Ricoy L, Ferrbudez PB. Pyelonephritis and pregnancy. Our experience in a general hospital. An Med Interna. 2007;24(12):585-587.

10. Shea K, Hilburger E, Baroco P, et al. Successful treatment of vancomycinresistant enterococcus faecium pyelonephritis with daptomycin during pregnancy. Ann Pharmacother. 2008;42(5):722-725.

11. Naber KG. Efficacy and safety of the phytotherapeutic drug Canephron ${ }^{\circledR}$ $\mathrm{N}$ in prevention and treatment of urogenital and gestational disease: review of clinical experience in Eastern Europe and Central Asia. Res Rep Urol. 2013;4(5):39-46. 